\title{
Characterisation of the Permafrost Carbon Pool
}

\author{
P. Kuhry, ${ }^{1 *}$ G. Grosse, ${ }^{2}$ J. W. Harden, ${ }^{3}$ G. Hugelius, ${ }^{1}$ C. D. Koven, ${ }^{4}$ C-L. Ping, ${ }^{5}$ L. Schirrmeister ${ }^{6}$ and C. Tarnocai ${ }^{7}$ \\ ${ }^{1}$ Department of Physical Geography and Quaternary Geology, Stockholm University, Stockholm, Sweden \\ 2 Geophysical Institute, University of Alaska Fairbanks, Fairbanks, AK, USA \\ ${ }^{3}$ US Geological Survey, Menlo Park, CA, USA \\ ${ }^{4}$ Lawrence Berkeley National Laboratory, Berkeley, CA, USA \\ 5 Palmer Research Center, University of Alaska Fairbanks, Fairbanks, AK, USA \\ 6 Alfred Wegener Institute, Potsdam, Germany \\ 7 Agriculture and Agri-Food Canada, Ottawa, Ontario, Canada
}

\begin{abstract}
The current estimate of the soil organic carbon (SOC) pool in the northern permafrost region of 1672 Petagrams (Pg) $\mathrm{C}$ is much larger than previously reported and needs to be incorporated in global soil carbon (C) inventories. The Northern Circumpolar Soil Carbon Database (NCSCD), extended to include the range 0-300 cm, is now available online for wider use by the scientific community. An important future aim is to provide quantitative uncertainty ranges for $\mathrm{C}$ pool estimates. Recent studies have greatly improved understanding of the regional patterns, landscape distribution and vertical (soil horizon) partitioning of the permafrost $\mathrm{C}$ pool in the upper $3 \mathrm{~m}$ of soils. However, the deeper $\mathrm{C}$ pools in unconsolidated Quaternary deposits need to be better constrained. A general lability classification of the permafrost $\mathrm{C}$ pool should be developed to address potential $\mathrm{C}$ release upon thaw. The permafrost $\mathrm{C}$ pool and its dynamics are beginning to be incorporated into Earth System models, although key periglacial processes such as thermokarst still need to be properly represented to obtain a better quantification of the full permafrost $\mathrm{C}$ feedback on global climate change. Copyright (C) 2013 John Wiley \& Sons, Ltd.
\end{abstract}

KEY WORDS: northern terrestrial permafrost; carbon pools; databases; uncertainties

\section{INTRODUCTION}

Research on the terrestrial permafrost carbon (C) pool has increased significantly in the last decade, as a result of the widely held perception that there could be a potentially significant positive feedback on global warming et al., 2008; Kuhry et al., 2010). The remobilisation of soil organic carbon (SOC) stocks through the thaw of previously frozen ground and their subsequent decomposition with the release of greenhouse gases may accelerate and intensify current warming. A widespread increase in permafrost temperatures is already underway in the circumpolar North as a result of recent climate warming (Romanovsky et al., 2010).

Tarnocai et al. (2009) provided a new estimate for the SOC pool in the northern permafrost region of $1672 \mathrm{Pg} \mathrm{C}$,

* Correspondence to: P. Kuhry, Department of Physical Geography and Quaternary Geology, Stockholm University, SE-106 91 Stockholm, Sweden. E-mail: peter.kuhry@ natgeo.su.se from thawing permafrost (e.g. Zimov et al., 2006a; Schuur

which is much higher than values previously reported (Ciais, 2009). This represents over twice the amount of $\mathrm{C}$ in the present atmosphere and more than three times the total C pool in the global forest biomass (Houghton, 2007). Part of the older permafrost $C$ is starting to decompose as a result of thaw (Schuur et al., 2009). While the potential feedback is large, the permafrost $\mathrm{C}$ pool and periglacial processes of remobilisation are not yet properly addressed in Earth System models and future projections of atmospheric greenhouse gas concentrations (Grosse et al., 2011a).

Large uncertainties remain concerning the future rates of global warming, permafrost thaw, the total permafrost $\mathrm{C}$ pool, the amount of $\mathrm{C}$ that will be remobilised and its decomposition pathways. Particular challenges related to the permafrost environment are: (1) the fine mosaic-like distribution of both SOC pools and ground ice in the landscape; (2) how $\mathrm{C}$ remobilisation from localised but relatively abrupt periglacial processes, such as thermokarst formation, expansion and drainage, and coastal erosion, may enhance the more widespread but gradual release of $\mathrm{C}$ stocks from deepening of 
the active layer ('pulse' vs 'press' disturbances; Grosse et al., 2011b); and (3) the potential decomposability (lability) of the $\mathrm{C}$ stocks upon thaw. Research networks such as the Belowground Carbon Pools in Permafrost Regions (CAPP) project of the IPA (e.g. Kuhry et al., 2010) and the National Science Foundation (NSF)-funded Research Coordination Network (RCN) on the Vulnerability of Permafrost Carbon (e.g. Schuur et al., 2011) are currently focusing on these issues, with a number of ongoing projects, such as the Nordic-funded DEFROST (http://www.ncoe-defrost.org/ home/), the European Union-funded PAGE21 (http://page21. org/), the United States Geological Survey (USGS)-funded FOCSY (http://carbon.wr.usgs.gov/fatecarbon.html) and the Department of Energy (DOE)-funded NGEE-Arctic (http:// ngee-arctic.ornl.gov), all aiming to contribute new pedon data to further improve data coverage and reduce uncertainties in the permafrost $\mathrm{C}$ database.

Tarnocai et al. (2009) highlighted large uncertainties in stock estimates, particularly those concerning the Eurasian and High Arctic sectors, the deeper (1-3 m) cryoturbated soils, and deltaic and ice-rich Yedoma deposits ( $>3-\mathrm{m}$ depth). This review summarises recent and ongoing efforts to improve the estimates of these stocks, to describe their regional, landscape and soil horizon distributions, to quantify uncertainty ranges and to provide data in formats useful to the wider scientific community.

\section{SOC MASS BETWEEN 0-300 CM IN THE NORTHERN PERMAFROST REGION}

The northern permafrost region used in the SOC assessment was delineated by Brown et al. (1997), but excludes permafrost areas in mid-latitude mountains (e.g. the Alps, the Tibetan Plateau) that are not continuous with permafrost areas of high-latitude lowlands. The estimates from Tarnocai et al. (2009) of SOC mass in the northern permafrost region for $0-100-\mathrm{cm}$ depth (Figure 1) are now available in the online version of the Northern Circumpolar Soil Carbon Database (NCSCD) (http://www.bbcc.su.se/ data/ncscd; Hugelius et al., 2013a). The NCSCD links pedons from the northern permafrost region to several digitised regional or national soil maps to produce a combined circumpolar coverage. The data are provided in different geographic file formats, including gridded files with varying spatial resolutions. The northern permafrost region is dominated by permafrost-affected soils (Gelisols), but its southern part with discontinuous permafrost (isolated, sporadic and widespread discontinuous zones) includes areas of non-permafrost soils that are incorporated in the calculation of stocks. In the paragraphs below, the estimated SOC masses from Tarnocai et al. (2009) are summarised for depths of 0-30, 0-100, 100-200 and 200-300 cm, and for the total 0-300-cm depth (Table 1).

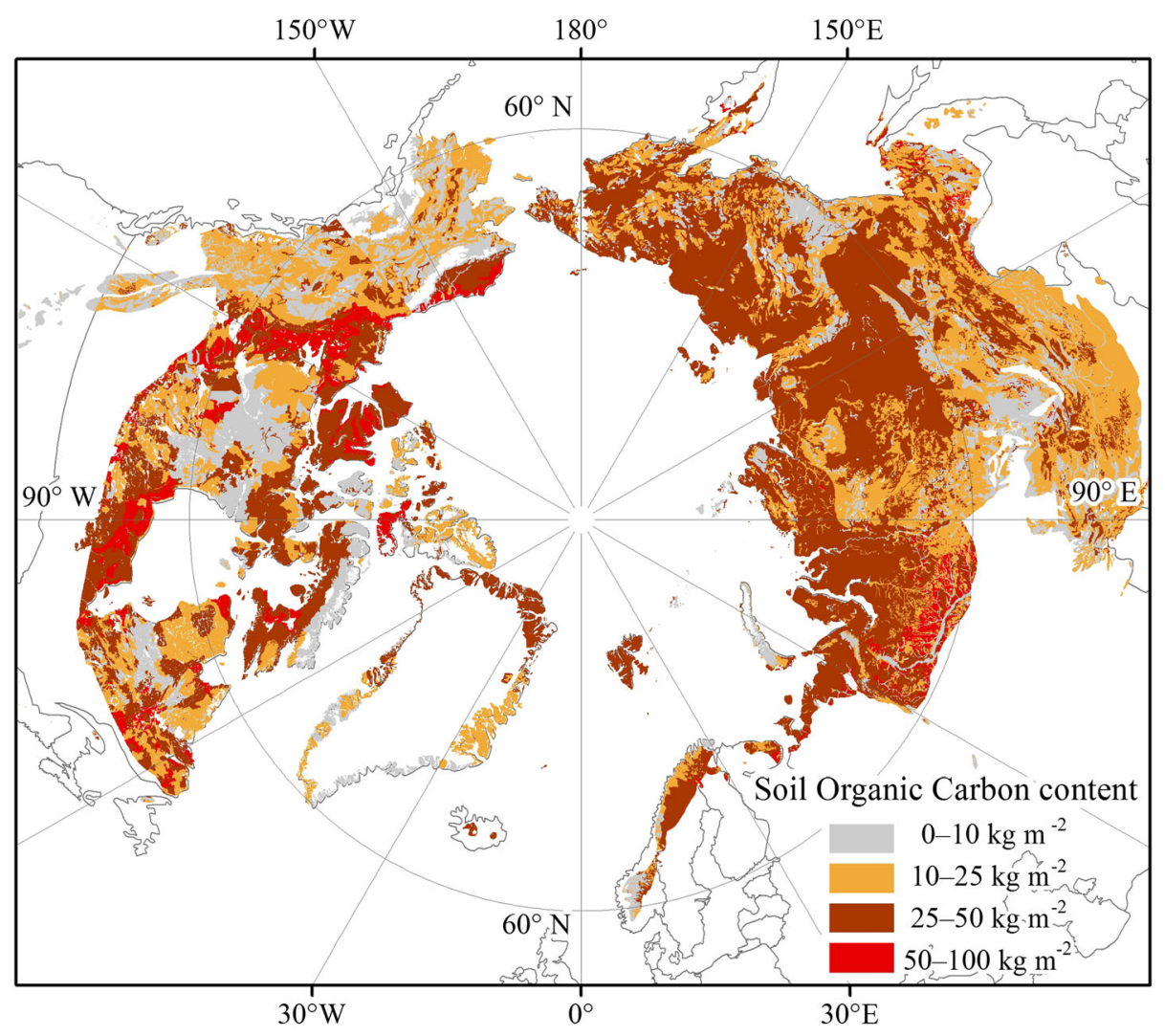

Figure 1 Distribution of soil organic carbon at 0-100-cm depth in the northern circumpolar permafrost region (adapted from Tarnocai et al., 2009; @ 2009 American Geophysical Union; reproduced by permission of the American Geophysical Union). 
Table 1 Soil organic carbon mass values to a depth of $300 \mathrm{~cm}$ for major soil groups in the northern circumpolar permafrost region (modified from Tarnocai et al., 2009; (C) 2009 American Geophysical Union; reproduced by permission of the American Geophysical Union).

\begin{tabular}{|c|c|c|c|c|c|}
\hline \multirow[b]{2}{*}{ Soil $^{\mathrm{a}}$} & \multicolumn{5}{|c|}{ Soil organic carbon mass $(\mathrm{Pg})$} \\
\hline & $0-30 \mathrm{~cm}$ & $0-100 \mathrm{~cm}$ & $100-200 \mathrm{~cm}$ & $200-300 \mathrm{~cm}$ & $0-300 \mathrm{~cm}$ \\
\hline Turbels & 80.4 & 211.9 & 207.2 & 162.2 & 581.3 \\
\hline Orthels & 23.7 & 51.3 & 1.7 & 0 & 53.0 \\
\hline Histels & 22.3 & 88.3 & - & - & $183.7^{\mathrm{c}}$ \\
\hline Subtotals Gelisols & 126.5 & 351.5 & - & - & 818.0 \\
\hline Non-Gelisols, mineral $^{\mathrm{b}}$ & 48.6 & 82.1 & 29.6 & 0 & 111.7 \\
\hline Histosols & 16.3 & 62.2 & - & - & $94.3^{\mathrm{c}}$ \\
\hline Subtotals non-Gelisols & 64.8 & 144.3 & - & - & 206.0 \\
\hline Totals & 191.3 & 495.8 & - & - & 1024.0 \\
\hline
\end{tabular}

${ }^{a} U S$ Soil Taxonomy (Soil Survey Staff, 1999).

bIncludes Alfisols, Inceptisols, Spodosols, Molisols, Entisols, Aridisols, Vertisols, Andisols and the Aqu- and Natric-suborders.

${ }^{\mathrm{c}}$ Calculated for the total depths of various peat deposits but not separated into layers for depths $>100 \mathrm{~cm}$.

The estimates of SOC masses for depths of $0-30 \mathrm{~cm}$ and $0-100 \mathrm{~cm}$ (Table 1) are based on a total of 1778 pedons in the NCSCD. The SOC mass for the $0-30-\mathrm{cm}$ depth corresponds to the surface layer of the soil column, which contains most of the recently deposited organic matter. The total SOC mass in this layer is $191 \mathrm{Pg}$, with permafrost-affected mineral cryoturbated soils (Turbels) containing the largest amount (80 Pg or $42 \%$ ) and other permafrost-affected mineral (Orthels) and organic soils (Histels) each containing less than a third of what is stored in Turbels (24 Pg C and $22 \mathrm{Pg} \mathrm{C}$, respectively, or about $12 \%$ each). The non-permafrost-affected soils and peat deposits in this depth range contain $65 \mathrm{Pg}$ or 34 per cent of the SOC mass. It should be noted, however, that even in permafrost-affected soils, the $0-30-\mathrm{cm}$ depth is entirely within the active layer. The total SOC mass for the $0-100-\mathrm{cm}$ depth is estimated at $496 \mathrm{Pg}$. Turbels again contain the largest amount of SOC (212 Pg or 43\%), with the second largest amount (88 Pg C or 18\%) occurring in permafrost-affected peat deposits (Histels). The nonpermafrost soils at this depth correspond to $144 \mathrm{Pg}$ or 29 per cent of the SOC mass.

The total SOC mass for the $100-300-\mathrm{cm}$ depth is approximately $528 \mathrm{Pg}$. According to Tarnocai et al. (2009), Turbels are the major contributors of SOC mass for this depth interval (369 Pg or 70\%). The SOC mass for Histels represents the second largest pool (95 Pg or $18 \%)$. Most unfrozen soils in the northern permafrost region contain very small amounts of SOC in the $100-300-\mathrm{cm}$ depth with the exception of Histosols (32 Pg or $6 \%$ ).

A large portion of the $1024 \mathrm{Pg}$ SOC estimated for the 0-300-cm depth interval (818 Pg or $80 \%$ ) occurs in permafrost-affected soils with Turbels contributing most (581 Pg C or 57\%). The non-permafrost soils contain approximately $206 \mathrm{Pg} \mathrm{C}(20 \%)$. However, at least the 0-30-cm depth interval in Gelisols with $126 \mathrm{Pg} \mathrm{C}$ thaws out seasonally, and in many permafrost soils the active layer is much deeper, so that in total $>332 \mathrm{Pg} \mathrm{C}$ (or $>33 \%$ of the total SOC mass in the $0-300-\mathrm{cm}$ depth) is in seasonally or perennially thawed ground. Turbels contain approximately 38 per cent of their SOC mass in the $0-100-\mathrm{cm}$ depth, 33 per cent in the 100-200-cm depth and 28 per cent in the $200-300-\mathrm{cm}$ depth. Therefore, about two-thirds of the SOC mass is missed if only the $0-100-\mathrm{cm}$ depth layer is sampled, although the 100-300$\mathrm{cm}$ depth estimates are based on only eight deep Turbel pedons (Tarnocai et al., 2009).

The estimates from Tarnocai et al. (2009) of SOC masses in the 100-200, 200-300 and 0-300-cm depth ranges (Table 1) are based on very limited field data (46 Canadian pedons) and were originally not included in the NCSCD. However, additional pedon data were recently compiled and the updated version of the NCSCD (v2) includes spatially distributed SOC mass estimates in the 100-200-cm and 200-300-cm depth ranges based on 528 and 358 pedons, respectively, from around the northern permafrost region (Hugelius et al., 2013b), including profiles used in Harden et al. (2012).

Many global estimates of SOC do not account for pedogenic processes unique to permafrost environments (Tarnocai and Broll, 2008). The deep C storage in Turbels and Histels/Histosols explains, to some extent, why smaller SOC pool estimates were previously reported for the region. Widely cited earlier studies, such as Schlesinger (1977) and Post et al. (1982), provided estimates for the top metre of soil only and are based on a very limited number of pedons. The combined tundra and alpine ecosystems of the world $\left(\mathrm{ca} .8 \times 10^{6} \mathrm{~km}^{2}\right)$ are represented in these studies by 21 and 48 sites, respectively. Most of the more recent global SOC estimates converge around 1500-1600 Pg C for the top metre of soil, with an additional 500-900 Pg C stored in the second metre (Eswaran et al., 1993; Batjes, 1996; Jobbagy and Jackson, 2000; Hiederer and Kochy, 2011). Inclusion of the new, higher estimate for the permafrost $\mathrm{C}$ pool would significantly increase the estimates for global soil C storage. 


\section{SOC MASS IN DEEPER DEPOSITS ( $>300 \mathrm{CM}$ ) OF THE NORTHERN PERMAFROST REGION}

On the basis of estimates byZimov et al. (2006b) for Yedoma C stocks of the order of $450 \mathrm{Pg}$, Tarnocai et al.(2009) calculated the deep SOC mass below 3-m depth in Yedoma at $407 \mathrm{Pg} \mathrm{C}$. Confidence in this estimate was very low due to the very limited data. The original estimates for Yedoma $\mathrm{C}$ stocks by Zimov et al. (2006b) were based on a total surface area of 1 million square kilometres of Siberian and central Alaskan ice-rich, fine-grained deposits, with an average thickness of $25 \mathrm{~m}$, an average bulk density of $1.65 \mathrm{~g} / \mathrm{cm}^{3}$, a C content of 2.6 per cent and a massive ice (ice wedge) content of about 50 per cent. However, each of these values is associated with large uncertainties.

Yedoma has been mapped locally at a fine scale, but no high-resolution Siberian or panarctic maps have been published. The datasets currently used in upscaling are small-scale maps that show a generalised Yedoma distribution over broad regions in central and eastern Siberia (e.g. Romanovskii, 1993; Grigoriev and Kunitsky, 2000). In a new effort, higher-resolution map data (Grosse et al., 2013a) were synthesised to obtain a better understanding of the spatial distribution of Yedoma in the circumpolar North. For regions where Yedoma is known to occur extensively, Quaternary geological maps on a scale of 1:1 000 000 were digitised and units identified as Yedoma were extracted and merged. For some regions, the finer-scale assessment resulted in a substantial reduction in the Yedoma area of more than 70 per cent, and areas previously assigned as Yedoma are now classified as various other types of deposits (Figure 2). The impact of these changes on the total permafrost $\mathrm{C}$ pool has to be evaluated carefully in relation to other deposits that may also contain large amounts of SOC.

Detailed geochemical analyses of sections from the Yedoma of northern Siberia by Schirrmeister et al. (2011) pointed out that different types of deposits are incorporated into the upper permafrost zone, including the typical ice-rich, fine-grained 'Yedoma Ice Complex' of the late Pleistocene mammoth tundra-steppe, Holocene and Weichselian peat, fluvial and alluvial deposits, lacustrine deposits in (former) thermokarst depressions and older Ice Complex deposits. These deposits vary greatly in ice content (22-59\% of wet weight), estimated bulk density $\left(0.35-1.43 \mathrm{~g} / \mathrm{cm}^{3}\right)$ and $C$ content $(0.5-10.9 \%$ of dry weight). The $\mathrm{C}$ content of these deposits averages around the previously estimated mean of 2.6 per cent (Zimov et al., 2006a), but dry bulk densities of the various types of deposits are consistently lower than the average value of $1.65 \mathrm{~g} / \mathrm{cm}^{3}$ used by Zimov et al. (2006a). In addition, at the classical Yedoma site of Duvanny Yar (lower Kolyma), the bulk density of the homogeneous Yedoma sequences ranges between $0.4 \mathrm{~g} / \mathrm{cm}^{3}$ and $1.2 \mathrm{~g} / \mathrm{cm}^{3}$, primarily due to intrasedimental ice content (Strauss et al., 2012). As Schirrmeister et al. (2011) point out, this adjustment of dry bulk density alone would reduce the total Yedoma $\mathrm{C}$ pool by about $25-50$ per cent. However, many uncertainties remain regarding the total area, average depth, massive ice volume and geochemical properties of the Yedoma Ice Complex, as well as other unconsolidated frozen deposits.

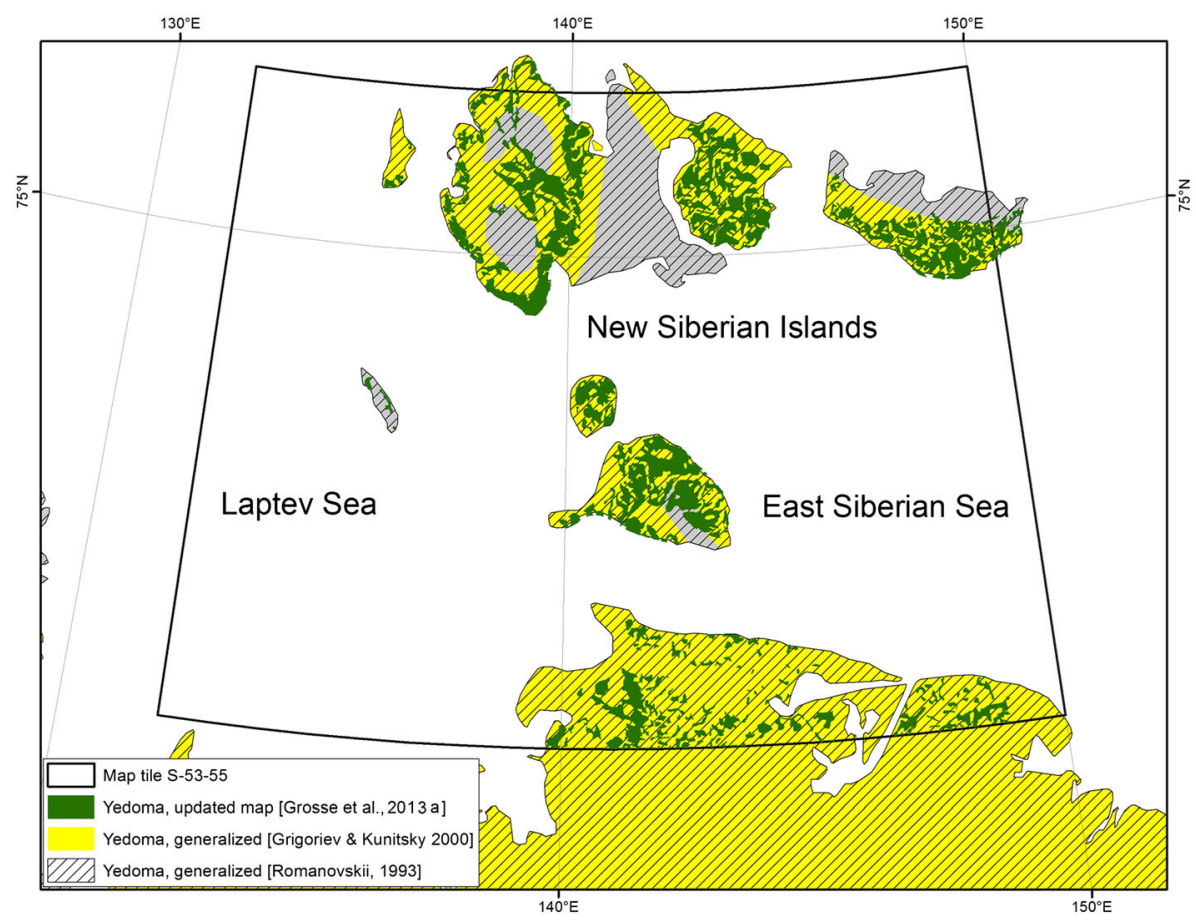

Figure 2 Updated distribution of Yedoma based on a digitised Russian Quaternary geology map for the New Siberian Islands (map tile S-53-55). The proportion of landscape mapped as Yedoma is reduced from 100 per cent (Romanovskii, 1993) to 26 per cent (Grosse et al., 2013a). 
Tarnocai et al. (2009) estimated a stock of $241 \mathrm{Pg} \mathrm{C}$ in deposits below $3 \mathrm{~m}$ of the major Arctic river deltas, the majority of which is stored in permafrost soils. This estimate has very low confidence as it is based on only two pedons from the Mackenzie Delta. Recently, Zubrzycki et al. (2012) surveyed in detail the $0-100-\mathrm{cm}$ soil C stocks of the Lena Delta, and data from a profile to 4-m depth from the same area were provided by Boike et al. (2012). In addition, Ping et al. (2011) presented C stocks in the upper $3 \mathrm{~m}$ of 13 delta sites along the Beaufort Sea coast of Alaska. Despite these recent data, more studies on deep SOC $(>3 \mathrm{~m})$ in Arctic deltas are necessary, because they represent a portion of the environment where there has been active deposition and burial of soil C, often since the late Pleistocene.

\section{REGIONAL GRADIENTS IN THE PERMAFROST SOC POOL}

The three Gelisol suborders are not equally distributed across the northern circumpolar permafrost region. Turbels are most extensive in the more northern areas with continuous permafrost, whereas Orthels and Histels are more prominent in the southern areas with more discontinuous permafrost (Tarnocai et al., 2009; Harden et al., 2012).

The $\mathrm{C}$ stores in the upper $100 \mathrm{~cm}$ of permafrost-affected upland soils of a North American transect follow a latitudinal gradient, increasing southwards from $16 \mathrm{~kg} \mathrm{C} / \mathrm{m}^{2}$ in the High Arctic to $51 \mathrm{~kg} \mathrm{C} / \mathrm{m}^{2}$ in the Low Arctic, and then decreasing to $44 \mathrm{~kg} \mathrm{C} / \mathrm{m}^{2}$ in the boreal forest. In the continuous permafrost of the High/Low Arctic region, 70-86 per cent of the total C pool in Turbels is cryoturbated or buried such that it is stored in the lower active layer and upper permafrost. However, in the discontinuous permafrost of the Boreal/Subarctic region, only about 37 per cent of the $\mathrm{C}$ stored in Turbels is found in the lower active layer and upper permafrost (Ping et al., 2008; Johnson et al., 2011). In northeastern European Russia, the proportion of $\mathrm{C}$ stored in cryoturbated organic-rich soil horizons in the upper $100 \mathrm{~cm}$ of Turbels increases from 44 per cent in the forest-tundra located in the sporadic permafrost zone, to 69 per cent in open tundra further north in the discontinuous permafrost zone (Hugelius et al., 2011).

In contrast to Turbels, Histels with deep perennially frozen peat deposits are mostly confined to the northern discontinuous and southern continuous permafrost zones. Further north, the peat layer of the abundant polygonal wetlands becomes too shallow $(<40 \mathrm{~cm})$ for the soil to be considered a Histel (Soil Survey Staff, 1999). Furthermore, most of the surficial peaty material, the 'histic' horizon, is in the active layer. In the Usa Basin lowlands of northeastern European Russia, which extend from permafrost-free terrain to the southern continuous permafrost zone, $>95$ per cent of the total perennially frozen SOC stock, calculated for the upper $100 \mathrm{~cm}$ of mineral soils and the total depth of peat deposits, is in palsas and peat plateaus (Hugelius and Kuhry, 2009).

\section{TYPICAL VERTICAL DISTRIBUTIONS OF THE PERMAFROST SOC POOL}

In addition to improving estimates for the total SOC pool in the three different Gelisol suborders, the vertical distribution
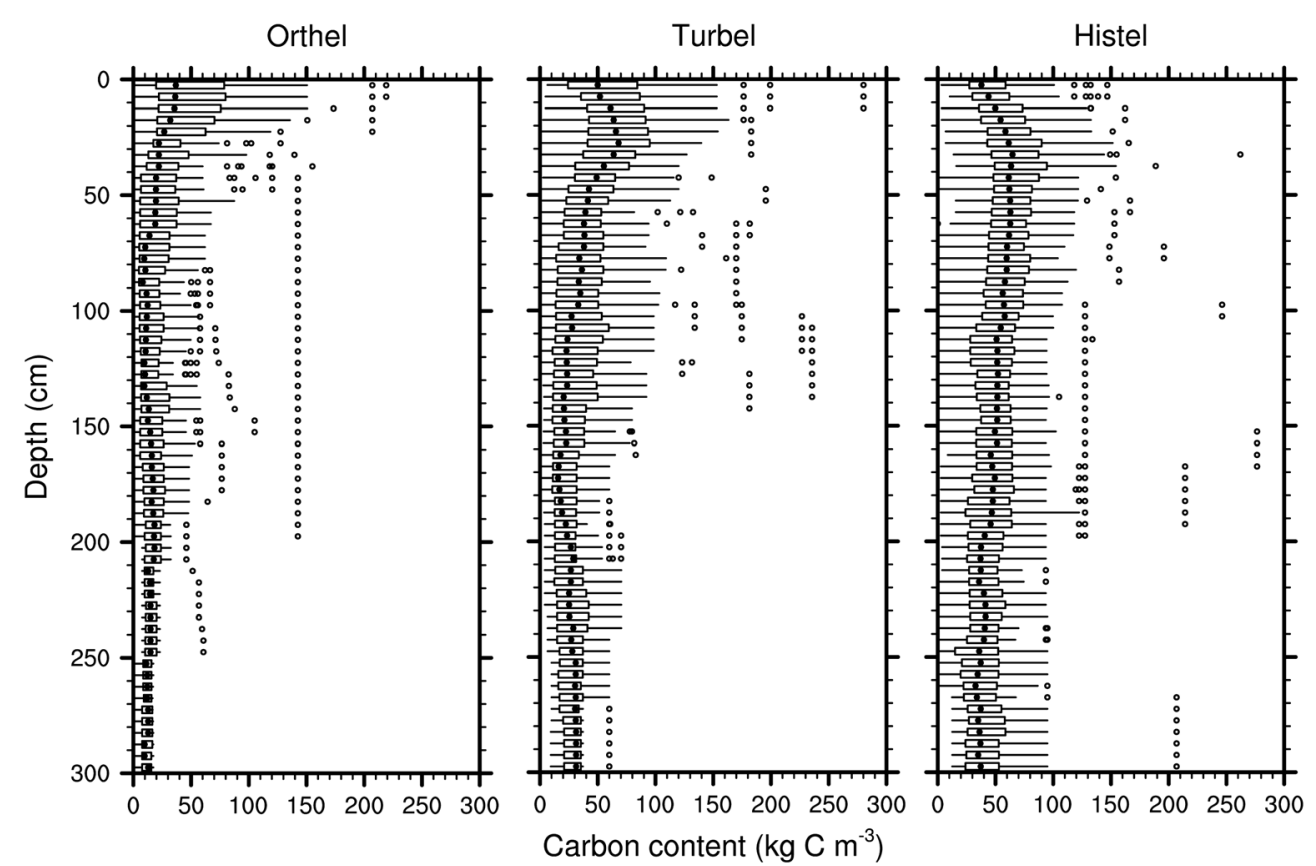

Figure 3 Box-whisker plots and maximum outliers of carbon density depth profiles for Gelisol suborders (Harden et al., 2012, supplemental materials; @ 2012 American Geophysical Union; reproduced by permission of the American Geophysical Union). 
of $\mathrm{C}$ in these soils is important for simplified estimates of $\mathrm{C}$ vulnerability and for constraining permafrost $\mathrm{C}$ models. Harden et al. (2012) calculated the average $\mathrm{C}$ content and variability of 231 pedons in $5-\mathrm{cm}$ increments for $0-300-\mathrm{cm}$ depth in order to compare C-depth trends among the suborders (Figure 3). Only 38 pedons reached the full depth of $300 \mathrm{~cm}$. Histels (80 pedons) maintain high-average $\mathrm{C}$ content values throughout the profile, although a slight decreasing trend can be observed with increasing depth as more pedons cross the peat/mineral transition. This is also evident from the high $\mathrm{C}$ content outliers at greater depths. Orthels (45 pedons) have the lowest $\mathrm{C}$ content throughout, which decreases rapidly below the top organic layer indicating a lack of cryoturbation or peat accumulation. Turbels (106 pedons) display higher $\mathrm{C}$ content than Orthels with some very high outliers representing discrete layers of buried deep cryoturbated organic material. We do not have maps or sufficient observations of soil depths over the permafrost region. In soils where the bedrock contact is shallower than $3 \mathrm{~m}$, the total SOC content will be lower.

The vertical distribution of the permafrost SOC pool is important for assessment of the impact of the anticipated gradual deepening of the active layer on remobilisation of the permafrost $\mathrm{C}$ pool. In addition to soil type and depth, Harden et al. (2012) also separated the $\mathrm{C}$ pool by horizon designation to highlight differences in the quantity and $\mathrm{C} / \mathrm{N}$ ratio of SOC in various types of soil horizons (organic, mineral, buried or cryoturbated) exposed to thawing. Harden et al. (2012) present preliminary results on the total amount of newly thawed SOC under different scenarios of global warming and active-layer deepening by the end of the $21^{\text {st }}$ century based upon updated vertical $\mathrm{C}$ profiles (http://www.fluxdata.org/NSCN/SitePages/Home.aspx) and the Community Climate System Model. These are $214 \mathrm{Pg}$ $\mathrm{C}$ and $379 \mathrm{Pg} \mathrm{C}$ (best estimates) for the RCP4.5 and RCP8.5 scenarios, respectively, which do not include changes in $\mathrm{C}$ cycling within the present active layer. The authors accounted for the vulnerabilities of SOC to combustion (organic horizons), decomposition (all horizons) and hydrologic inputs (all horizons) over thawing scenarios, and recommended further evaluation of regional gradients within the permafrost $\mathrm{C}$ pool allocated to each suborder, as discussed above, and the assessment of abrupt processes of permafrost $\mathrm{C}$ remobilisation such as thermokarst and coastal erosion.

\section{REGIONAL ESTIMATES OF POTENTIAL PERMA- FROST C REMOBILISATION}

Hugelius et al. (2011) combined very high-resolution maps of SOC storage ( 2.4 x 2.4-m resolution) from the Seida area in northeast European Russia with simulations of gradual (i.e. active-layer deepening) and abrupt (i.e. thermokarst expansion) permafrost thaw to assess potential SOC remobilisation under future climate warming. The active-layer thickness dynamics for seven different land cover/soil classes from 1980 to 2099 under the SRES A1B scenario were modelled with the Geophysical Institute Permafrost Laboratory transient spatially distributed permafrost model (GIPL2), using a very high-resolution $(4 \times 4 \mathrm{~km})$ regional climate model (Stendel et al., 2011). The lateral expansion of current thermokarst in an uplifted permafrost peat plateau was simulated using a GIS-based buffer analysis. In the Seida area, thermokarst lakes are (almost) entirely confined to the peat plateau areas.

The simulations showed that active-layer deepening is expected to increase the pool of active-layer SOC from 29 per cent to 58 per cent of the total landscape SOC store (Figure 4a). The main contributors to this increase are the moist and wet shrub-moss tundra classes, which currently have a thick top organic layer and a relatively shallow active layer. Only small changes are expected in the active-layer depth of peat plateaus because the generally dry peat surface insulates the underlying permafrost. The most likely process of $\mathrm{C}$ remobilisation in these peat plateaus is an increase in thermokarst lake area. An average 30-m lateral expansion
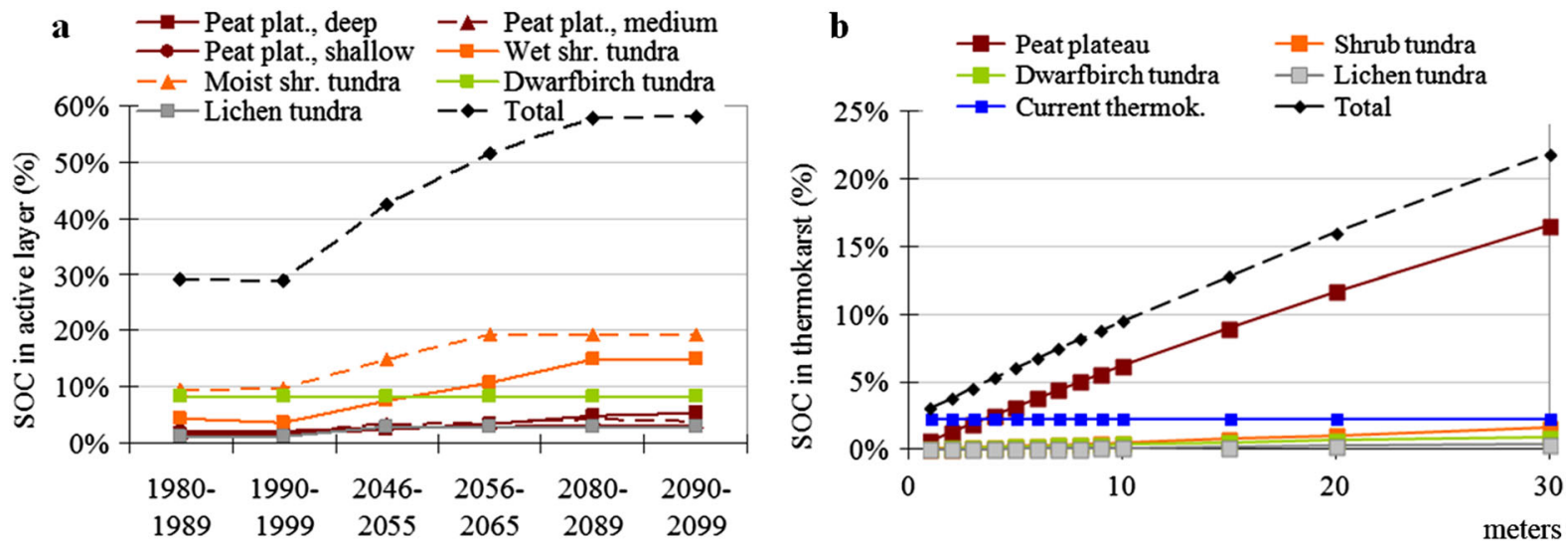

Figure 4 Increase in thawed soil organic carbon (SOC) following active-layer deepening and thermokarst expansion. (a) Percentage of total SOC storage in the active layer in the upper $3 \mathrm{~m}$ of seven different land cover/soil classes in the Seida area for time slices from 1980 to 2099 . (b) Cumulative increase in SOC in thermokarst (percentage of SOC stored in the whole Seida study area) following lateral expansion (1-30 m) of current thermokarst in the Seida peat plateau (modified from Hugelius et al., 2011; (C) 2011 American Geophysical Union; reproduced by permission of the American Geophysical Union). 
of current thermokarst would increase the amount of SOC stored in thermokarst lakes and fens from 2 per cent to 22 per cent of all SOC in the Seida study area (Figure 4b).

Hugelius et al. (2011) conclude that active-layer deepening will mainly affect mineral soil horizons while thermokarst expansion will be important in remobilising organic soil deposits. The organic matter in perennially frozen peat plateau deposits is less decomposed than organic matter below the active layer in the surrounding upland soil mineral horizons (Hugelius et al., 2012) and could, therefore, decay faster following permafrost thaw. Thus, in the Seida area, active-layer deepening is likely to remobilise more frozen SOC by the end of this century, but thermokarst expansion may well result in larger $\mathrm{C}$ releases from the more labile peat. However, decomposition pathways have to be considered. Much of the peat ending up in thermokarst lakes will decompose relatively slowly under anaerobic conditions, until the lake drains. On the other hand, this process will lead to a high emission of methane $\left(\mathrm{CH}_{4}\right)$, which in the short term is a more potent greenhouse gas than carbon dioxide $\left(\mathrm{CO}_{2}\right)$.

These regional estimates of future $\mathrm{C}$ remobilisation due to permafrost thawing in northeast European Russia highlight the current difficulties in assessing the rate at which permafrost $C$ will thaw, even if we accept a single climate model and warming scenario. Whereas gradual deepening of the active layer for different land cover/soil classes can be projected quite accurately with the GIPL 2 model (if we assume no large-scale changes in vegetation cover and local surface hydrology due to the warming and thawing), the rate of thermokarst processes is currently much more difficult to quantify. In a remote sensing time series of thermokarst dynamics in three subarctic peat plateau/thermokarst complexes, Sannel and Kuhry (2011) found a maximum lateral erosion of the peat plateau edge of $7 \mathrm{~m}$ per decade. However, very few lakes demonstrated extensive erosion along their shorelines (Sannel and Brown, 2010). Therefore, a 30-m average expansion of thermokarst lakes in peatlands by the end of this century, as used above, can probably be considered an overestimate. In very ice-rich sediments and mineral soils such as on the Seward Peninsula of northwest Alaska, thermokarst lake expansion may reach average rates of $0.35-0.39 \mathrm{~m} / \mathrm{yr}$, to exceed a $30-\mathrm{m}$ buffer around such lakes by the end of the century (Jones et al., 2011). Rapid lake expansion in this area frequently leads to lake drainage, resulting in the expansion of wetlands where, after a few decades, substantial amounts of peat begin to accumulate (Jones et al., 2012). Predicting thermokarst processes at a northern circumpolar scale is difficult, due to their great variety and the many different types of terrain in which they occur (Grosse et al., 2013b).

\section{QUANTITATIVE UNCERTAINTY RANGES OF THE PERMAFROST C POOL}

Although we recognise that the pool of SOC stored in permafrost regions is very large and potentially vulnerable to remobilisation, little is known of the uncertainties in estimates of these stores. Uncertainties are related to errors due to sampling (e.g. field volume of samples to calculate dry bulk density), laboratory measurements (e.g. loss-onignition or $\mathrm{C}$ contents), limited pedon data, and the reliability and resolution of upscaling tools (e.g. land cover classifications and soil maps).

Tarnocai et al. (2009) used qualitative ranges for assessing uncertainty in different $\mathrm{C}$ stocks from 'very high to very low' confidence. Their upscaling approach, based on soil maps, recognises the occurrence of key pedogenic processes such as cryoturbation or peat formation in the soils. However, the various soil maps on which the upscaling was based utilised different soil classification systems, and had several resolutions (i.e. average polygon sizes) and various thematic approaches as to how fractions of different soil classes are represented within each polygon. These differences make quantitative estimates of uncertainty impractical. Pedogenic processes can only be indirectly inferred in land cover-based approaches as these only reflect the biophysical coverage at a site. However, some available land cover products have northern circumpolar coverage with good spatial resolution and associated ground-truth data that can be used to quantify spatial errors in upscaling. Kuhry et al. (2002), Hugelius et al. (2011) and Hugelius (2012) have shown that soil and land cover upscaling for the same region can result in very similar SOC estimates. A key objective remains to link the NCSCD to a northern circumpolar land cover classification to provide a second estimate of the northern permafrost $\mathrm{C}$ pool, which would also provide a means to calculate associated uncertainty ranges.

In a regional case study of the northern Usa River Basin (European Russian Arctic), Hugelius (2012) quantified upscaling uncertainties caused by natural variability or insufficient field sampling in different soil and land cover classes, and areal misrepresentation of land cover classes in the upscaling proxy. For SOC estimates based on land cover upscaling, the 95 per cent confidence interval for combined propagated errors from insufficient replication of natural variability in soils and spatial misrepresentation in the upscaling tool is $\pm 10-11$ per cent in top soils and to full pedon depth. Estimates for organic, permafrost and cryoturbated horizons are less constrained $( \pm 15 \%$, $\pm 18 \%$ and $\pm 78 \%$, respectively). The large uncertainty range for cryoturbated horizons is due to a combination of large variability and few pedons in the dataset (Hugelius, 2012). It should be noted, however, that results will depend on the landscape complexity and the SOC variability within classes and soil horizons, which can be expected to vary between regions.

\section{DISCUSSION}

In the most recent decade, there has been a large increase in the number of programmes, projects and publications 
dealing with the permafrost $\mathrm{C}$ pool and its potential remobilisation. Much progress has been made in improving estimates of the total SOC pool, and describing its regional, landscape and soil horizon partitioning. Uncertainties in C stock estimates remain, particularly for remote geographic regions and the deeper deposits. Some recent studies suggest that $\mathrm{C}$ stocks in the High Arctic might be underestimated (Horwath Burnham and Sletten, 2010), whereas estimates of Yedoma $\mathrm{C}$ stocks might be too high (Schirrmeister et al., 2011; Strauss et al., 2012). Much work is currently underway to further improve $\mathrm{C}$ stock data for the High Arctic (e.g. Svalbard, Greenland, Canadian archipelago) and Eurasian sectors, the deeper cryoturbated horizons and the deep $(>3 \mathrm{~m})$ Yedoma-type deposits. However, studies on deep river delta and other unconsolidated deep Quaternary (e.g. glaciofluvial, glaciolacustrine) deposits $(>3 \mathrm{~m})$ are greatly needed.

Furthermore, the strong interactions between climate, fire and permafrost should be carefully considered (e.g. Harden et al., 2006). Fires alter the thermal state of permafrost and can create thermokarst depressions and collapse scars in forested (Myers-Smith et al., 2008) and peatland ecosystems (Zoltai, 1993). Shifts in hydrology associated with thaw will impact the depth of burning where organic horizons are exposed (Turetsky et al., 2011). Tundra fires can contribute to large $C$ releases (Mack et al., 2011) and peat fires are known to reduce long-term $\mathrm{C}$ storage in peat deposits (Kuhry, 1994). These strong fire-permafrost interactions should be considered when evaluating the fate of permafrost $\mathrm{C}$ under future climate change.

The rates of global warming (and its amplification in the northern high latitudes) and associated permafrost thawing need to be better constrained, as thaw will dictate the total amount of newly exposed $\mathrm{C}$ made available for decomposition, combustion and hydrologic redistribution. The permafrost $\mathrm{C}$ pool and periglacial processes are starting to be incorporated in Earth System models. For example, Koven et al. (2009) simulated cryoturbation processes in permafrost-affected soils, greatly improving the total storage of SOC in their model; and Burke et al. (2012) and Harden et al. (2012) used projections of active-layer deepening and vertical distributions of the permafrost $\mathrm{C}$ pool to estimate the total amount of remobilised $\mathrm{C}$

A key uncertainty is to quantify the decomposability of remobilised permafrost $C$ (i.e. rates and pathways of future decay). Whereas the quantification of the total permafrost $\mathrm{C}$ pool has greatly improved in recent years, little is known about the potential decomposability of stored permafrost $C$. A lability assessment for different types of permafrost soils and deposits is urgently needed in order to improve the projections of future C release. Burke et al. (2012) approached this uncertainty by providing a range of likely aerobic and anaerobic decay rates and total amounts of $\mathrm{CO}_{2}$ and $\mathrm{CH}_{4}$ released (with their global warming potential) under different active-layer deepening scenarios. However, key periglacial processes affecting the thaw rate and surface hydrology were not considered. Their proper representation at sub-grid scales in Earth System models is necessary to fully assess the role of the large permafrost $\mathrm{C}$ pool in future global climate.

\section{CONCLUSIONS}

This paper presents recent advances in our understanding and representation of the large terrestrial $\mathrm{C}$ pool in the northern permafrost region and highlights some future challenges. We conclude that:

1. Estimates for the total permafrost $\mathrm{C}$ pool are much larger than those previously reported in global soil $\mathrm{C}$ surveys. Global soil $\mathrm{C}$ databases need to incorporate these results.

2. The estimates of SOC at $0-30,0-100,100-200$, 200-300 and 0-300-cm depths for different soil types linked to regional and northern circumpolar soil maps are available online in appropriate GIS formats for use by the wider scientific community.

3. Typical vertical depth distributions of SOC stocks at 5-cm increments in the three Gelisol suborders have been computed.

4. Particularly large uncertainties remain with pool estimates for deeper $(>3 \mathrm{~m})$ unconsolidated Quaternary deposits (Yedoma, deltaic, glaciofluvial, glaciolacustrine).

5. Uncertainty analysis of upscaled soil $\mathrm{C}$ estimates using the current NCSCD is difficult due to the heterogeneous character of the circumpolar soil map. Linking soil C data to available land cover classifications with coherent circumpolar coverage is an alternative, but much care is necessary as the biophysical characteristics of current land cover do not necessarily reflect long-term (often polygenetic) soil-forming processes.

6. A general classification of SOC lability in different soil types and horizons is urgently needed in order to assess the potential decomposability of $\mathrm{C}$ pools upon thawing.

7. The storage and vertical distribution of SOC in various soil types along climatic (hyperoceanic to hypercontinental zones) and permafrost (isolated to continuous zones) gradients should be considered when modelling future thaw in permafrost terrain.

8. Abrupt periglacial processes such as thermokarst dynamics and coastal erosion should be parameterised in Earth System models to account for their large C remobilisation potential.

9. The permafrost $\mathrm{C}$ feedback needs to be incorporated in future projections of climate change.

\section{ACKNOWLEDGEMENTS}

This paper is a contribution to the CAPP project of the IPA and the NSF-funded RCN on the Vulnerability of Permafrost Carbon. 


\section{REFERENCES}

Batjes NH. 1996. Total carbon and nitrogen in the soils of the world. European Journal of Soil Science 47: 151-163.

Boike J, Kattenstroth B, Abramova K, Bornemann N, Chetverova A, Fedorova I, Fröb K, Grigoriev M, Grüber M, Kutzbach L, Langer M, Minke M, Muster S, Piel K, Pfeiffer EM, Stoof G, Westermann S, Wischnewski K, Wille C, Hubberten HW. 2012. Baseline characteristics of climate, permafrost, and land cover from a new permafrost observatory in the Lena River Delta, Siberia (1998-2011). Biogeosciences Discussions 9: 1-58. DOI: 10.5194/bgd-91-2012

Brown J, Ferrians OJ, Jr, Heginbottom JA, Melinkov ES. 1997. Circum-Arctic Map of Permafrost and Ground Ice Conditions, Scale 1:10,000,000. US Geological Survey: Washington, DC.

Burke EJ, Hartley IP, Jones CD. 2012. Uncertainties in the global temperature change caused by carbon release from permafrost thawing. The Cryosphere 6: 1063-1076. DOI: $10.5194 / t c-6-1063-2012$

Ciais P. 2009. A geoscientist is astounded by Earth's huge frozen carbon deposits. Research Highlights. Nature 462: 393.

Eswaran H, Van Den Berg E, Reich P. 1993. Organic carbon in soils of the world. Soil Science Society of America Journal 57: 192-194.

Grigoriev MN, Kunitsky VV. 2000. Ice Complex of the Arctic coasts of Yakutia as a sediment source on the continental shelf. In Hydrometeorological and Biogeochemical Research in the Arctic Region, Vladivostok, Russia, Arctic Regional Centre. Dalnauka Press, 2, 109-116 (in Russian).

Grosse G, Romanovsky V, Jorgenson T, Anthony KW, Brown J, Overduin PP. 2011a. Vulnerability and Feedbacks of Permafrost to Climate Change. Eos Transactions AGU 92: 73. DOI: 10.1029/2011EO090001

Grosse G, Harden J, Turetsky M, McGuire AD, Camill P, Tarnocai C, Frolking S, Schuur EAG, Jorgenson T, Marchenko S, Romanovsky V, Wickland KP, French N, Waldrop M, Bourgeau-Chavez L, Striegl RG. 2011b. Vulnerability of high-latitude soil organic carbon in North America to disturbance. Journal of Geophysical Research 116: G00K06. DOI: 10.1029/ 2010JG001507.

Grosse G, Robinson JE, Bryant R, Taylor MD, Harper W, DeMasi A, Keiker-Snowman E, Veremeeva A, Harden J, Schirrmeister L. 2013a. Digital database of the distribution of late Pleistocene ice-rich syngenetic permafrost of the Yedoma Suite in East and Central Siberia, Russia. US Geological Survey Open-File Report, 2013-1078.

Grosse G, Jones B, Arp C. 2013b. Thermokarst lakes, drainage, and drained basins. In Treatise on Geomorphology, Shroder JF (ed). Academic Press: San Diego; 8, 325-353.

Harden JW, Manies KL, Turetsky MR, Neff JC. 2006. Effects of wildfire and permafrost on soil organic matter and soil climate in interior Alaska. Global Change Biology 12: 2391-2403. DOI: 10.1111/j.1365-2486. 2006.01255.x

Harden JW, Koven CD, Ping CL, Hugelius G, McGuire AD, Camill $\mathrm{P}$, Jorgenson $\mathrm{T}$, Kuhry P, Michaelson GJ, O'Donnell JA, Schuur EAG, Tarnocai C, Johnson K, Grosse G. 2012. Field information links permafrost carbon to physical vulnerabilities of thawing. Geophysical Research Letters 39: L15704. DOI: 10.1029/2012GL051958

Hiederer R, Kochy M. 2011. Global Soil Organic Carbon Estimates and the Harmonized World Soil Database. EUR 25225 EN. Publications Office of the European Union, Luxembourg: 79pp.

Houghton RA. 2007. Balancing the Global Carbon Budget. Annual Review of Earth and Planetary Sciences 35: 313-347.

Horwath Burnham J, Sletten RS. 2010. Spatial distribution of soil organic carbon in northwest Greenland and underestimates of high Arctic carbon stores. Global Biogeochemical Cycles 24(3): GB3012.

Hugelius G. 2012. Spatial upscaling using thematic maps: an analysis of uncertainties in permafrost soil carbon estimates. Global Biogeochemical Cycles 26: GB2026. DOI: 10.1029/2011GB004154

Hugelius G, Kuhry P. 2009. Landscape partitioning and environmental gradient analyses of soil organic carbon in a permafrost environment. Global Biogeochemical Cycles 23: GB3006. DOI: 10.1029/ 2008GB003419

Hugelius G, Virtanen T, Kaverin D, Pastukhov A, Rivkin F, Marchenko S, Romanovsky V, Kuhry P. 2011. High-resolution mapping of ecosystem carbon storage and potential effects of permafrost thaw in periglacial terrain, European Russian Arctic. Journal of Geophysical Research 116: G03024. DOI: 10.1029/2010JG001606

Hugelius G, Routh J, Kuhry P, Crill P. 2012. Mapping the degree of decomposition and thaw remobilization potential of soil organic matter in discontinuous permafrost terrain. Journal of Geophysical Research 117: G02030. DOI: 10.1029/ 2011JG001873

Hugelius G, Tarnocai C, Broll G, Canadell JG, Kuhry P, Swanson DK. 2013a. The Northern Circumpolar Soil Carbon Database: spatially distributed datasets of permafrost soil coverage and soil $\mathrm{C}$ storage in the northern permafrost regions. Earth System Science Data 5: 3-13. DOI: 10.5194/essd-5-3-2013

Hugelius G, Tarnocai C, Bockheim JG, Camill P, Elberling B, Grosse G, Harden JW, Johnson K, Jorgenson T, Koven C, Kuhry P, Michaelson G, Mishra U, Palmtag J, Ping C-L, O'Donnell J, Schirrmeister L, Schuur EAG, Sheng Y, Smith LC, Strauss J, Yu Z. 2013b. A new dataset for estimating organic carbon storage to $3 \mathrm{~m}$ depth in soils of the northern circumpolar permafrost region. Earth System Science Data Discussions 6: 73-93. DOI: 10.5194/essdd-6-732013

Jobbagy EG, Jackson RB. 2000. The vertical distribution of soil organic carbon and its relation to climate and vegetation. Ecological Applications 10: 423-436.

Johnson KD, Harden J, McGuire AD, Bliss NB, Bockheim JG, Clark M, NettletonHollingsworth T, Jorgenson MT, Kane ES, Mack M, O'Donnell J, Ping CL, Schuur EAG, Turetsky MR, Valentine DW. 2011. Soil carbon distribution in Alaska in relation to soilforming factors. Geoderma 167-168: 71-84.

Jones BM, Grosse G, Arp CD, Jones MC, Walter Anthony KM, Romanovsky VE. 2011. Modern thermokarst lake dynamics in the continuous permafrost zone, northern Seward Peninsula, Alaska. Journal of Geophysical Research 116: G00M03. DOI: $10.1029 / 2011$ jg001666

Jones MC, Grosse G, Jones BM, Walter Anthony K. 2012. Peat accumulation in drained thermokarst lake basins in continuous, ice-rich permafrost, northern Seward Peninsula, Alaska. Journal of Geophysical Research 117: G00M07. DOI: 10.1029/ 2011JG001766

Koven C, Friedlingstein P, Ciais P, Khvorostyanov D, Krinner G, Tarnocai C. 2009. On the formation of highlatitude soil carbon stocks: Effects of cryoturbation and insulation by organic matter in a land surface model. Geophysical Research Letters 36: L21501. DOI: 10.1029/2009GL040150

Kuhry P. 1994. The role of fire in the development of Sphagnum-dominated peatlands in western boreal Canada. Journal of Ecology 82: 899-910.

Kuhry P, Mazhitova GG, Forest PA, Deneva SV, Virtanen T, Kultti S. 2002. Upscaling soil organic carbon estimates for the Usa Basin (Northeast European Russia) using GIS-based landcover and soil classification schemes. Danish Journal of Geography 102: 11-25.

Kuhry P, Dorrepaal E, Hugelius G, Schuur EAG, Tarnocai C. 2010. Potential remobilization of below ground permafrost carbon under future global warming. Permafrost and 
Periglacial Processes 21: 208-214. DOI: 10. 1002/ppp.684

Mack MC, Bret-Harte MS, Hollingsworth TN, Jandt RR, Schuur EAG, Shaver GR, Verbyla DL. 2011. Carbon loss from an unprecedented Arctic tundra wildfire. Nature 475: 489-492.

Myers-Smith H, Harden JW, Wilmking M, Fuller CC, McGuire AD, Chapin FS, III. 2008. Wetland succession in a permafrost collapse: interactions between fire and thermokarst. Biogeosciences 5: 1273-1286.

Ping CL, Michaelson GJ, Jorgenson T, Kimble JM, Epstein H, Romanovsky VE, Walker DA. 2008. High stocks of soil organic carbon in North American Arctic region. Nature Geoscience 1: 615-619. DOI: 10. 1038/ngeo284

Ping CL, Michaelson GJ, Guo L, Jorgenson T, Kanevskiy M, Shur Y, Dou F, Liang J. 2011. Soil carbon and material fluxes across the eroding Alaska Beaufort Sea coastline. Journal of Geophysical Research 116. DOI: 10.1029/2010JG001588

Post WM, Emmanuel WR, Zinke PJ, Stangenberger AG. 1982. Soil carbon pools and world life zones. Nature 298: 156-159.

Romanovskii NN. 1993. Principles of Cryogenesis in the Lithosphere [Osnovy Kriogeneza Litosfery]. Izdatelstvo Moscow State University: Moscow; 335pp (in Russian).

Romanovsky VE, Smith S, Christiansen H. 2010. Permafrost thermal state in the polar Northern Hemisphere during the international polar year 2007-2009: a synthesis Permafrost and Periglacial Processes 21: 106-116. DOI: 10.1002/ppp.689

Sannel ABK, Brown IA. 2010. High resolution remote sensing identification of thermokarst lake dynamics in a subarctic peat plateau complex. Canadian Journal of Remote Sensing 36: S26-S40.

Sannel ABK, Kuhry P. 2011. Warming-induced destabilization of peat plateau/ thermokarst lake complexes. Journal of Geophysical Research 116: G03035. DOI: 10.1029/2010JG001635
Schirrmeister L, Grosse G, Wetterich S, Overduin PP, Strauss J, Schuur EAG, Hubberten HW. 2011. Fossil organic matter characteristics in permafrost deposits of the northeast Siberian Arctic. Journal of Geophysical Research 116: G00M02. DOI: 10.1029/2011JG001647

Schlesinger WH. 1977. Carbon balance in terrestrial detritus. Annual Review of Ecology and Systematics 8: 51-81.

Schuur EAG, Bockheim J, Canadell J, Euskirchen E, Field CB, Goryachkin SV, Hagemann S, Kuhry P, Lafleur P, Lee H, Mazhitova G, Nelson FE, Rinke A, Romanovsky V, Shiklomanov N, Tarnocai C, Venevsky S, Vogel JG, Zimov SA. 2008. Vulnerability of permafrost carbon to climate change: implications for the global carbon cycle. Bioscience 58: 701-714.

Schuur EAG, Vogel JG, Crummer KG, Lee H, Sickman JO, Osterkamp TE. 2009. The impact of permafrost thaw on old carbon release and net carbon exchange from tundra. Nature 459: 556-559.

Schuur EAG, Abbott BW, Bowden WB, Brovkin V, Camill P, Canadell JP, Chapin FS, III, Christensen TR, Chanton JP, Ciais P, Crill PM, Crosby BT, Czimczik CI, Grosse G, Harden J, Hayes DJ, Hugelius G, Jastrow JD, Kleinen T, Koven CD, Krinner G, Kuhry P, Lawrence DM, McGuire AD, Natali SM, O'Donnell JA, Ping CL, Rinke A, Riley WJ, Romanovsky VE, Sannel ABK, Schädel C, Schaefer K, Subin ZM, Tarnocai C, Turetsky M, Waldrop M, Walter-Anthony KM, Wickland KP, Wilson CJ, Zimov SA. 2011. High risk of permafrost thaw. Nature 480: $32-33$.

Soil Survey Staff. 1999. Soil Taxonomy, a Basic System of Soil Classification for Making and Interpreting Soil Surveys, $2{ }^{\text {nd }}$ Edition, Handbook No. 436. Natural Resources Conservation Service, US Department of Agriculture: Washington, DC; 869pp.

Stendel M, Christensen JH, Marchenko S, Romanovsky V, Daanen R, Rinke A, Matthes H, Kuhry P, Rivkin F, Kaverin D.
2011. Size matters - very high resolution permafrost simulations on the $4 \mathrm{~km}$ scale in northeast European Russia. Geophysical Research Abstracts 13: EGU2011-6493.

Strauss J, Schirrmeister L, Wetterich S, Borchers A, Davydov SP. 2012. Grain-size properties and organic-carbon stock of Yedoma Ice Complex permafrost from the Kolyma lowland, northeastern Siberia. Global Biogeochemical Cycles 26: GB3003. DOI: $10.1029 / 2011 \mathrm{~GB} 004104$

Tarnocai C, Broll G. 2008. Soil organic carbon stocks in the northern permafrost region and their role in climate change. In Proceedings of the Ninth International Conference on Permafrost, Kane DL and Hinkel KM (eds). Institute of Northern Engineering, University of Alaska Fairbanks, Fairbanks: 2, 1751-1755.

Tarnocai C, Canadell JG, Schuur EAG, Kuhry P, Mazhitova G, Zimov S. 2009. Soil Organic Carbon Pools in the Northern Circumpolar Permafrost Region. Global Biogeochemical Cycles 23: GB2023. DOI: 10.1029/2008GB03327

Turetsky MR, Donahue W, Benscoter BW. 2011. Experimental drying intensifies burning and carbon losses in a northern peatland. Nature Communications 2: 514. DOI: 10.1038/ncomms1523

Zimov SA, Schuur EAG, Chapin FS, III. 2006a. Permafrost and the Global Carbon Budget. Science 312: 1612-1613.

Zimov SA, Davydov SP, Zimova GM, Davydova AI, Schuur EAG, Dutta K, Chapin FS. 2006b. Permafrost carbon: stock and decomposability of a globally significant carbon pool. Geophysical Research Letters 33: L20502.

Zoltai SC. 1993. Cyclic development of permafrost in the peatlands of northwestern Alberta. Arctic and Alpine Research 25: 240246.

Zubrzycki S, Kutzbach L, Grosse G, Desyatkin A, Pfeiffer EM. 2012. Organic carbon and total nitrogen stocks in soils of the Lena River Delta. Biogeosciences Discussions 9: 17263-17311. DOI: 10.5194/bgd-9-17263-2012 